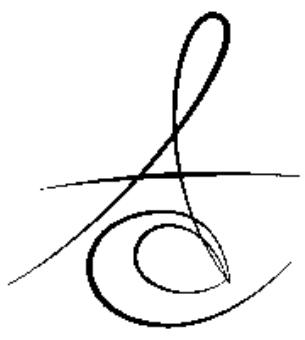

Makale Kodu/Article code: 2206

Makale Gönderilme tarihi: 25.03.2015

Kabul Tarihi: 06.05.2015

\section{İLACA BAĞLI DİŞETİ BÜYÜMESİ İKİ VAKA SUNUMU}

\section{DRUG-INDUCED GINGIVAL ENLARGEMENT TWO CASE REPORT}

\author{
Dt. Abdulsamet TANİK*
}

\author{
Dt. Fatih DEMİRCí $\dot{I}^{* *}$
}

\section{öz}

İlaca bağlı dişeti büyümeleri bazı sistemik ilaçların yan etkisi şeklinde oluşur. Hipertansiyon hastalarında kullanılan nifedipin ve organ nakli olan hastalarda organ reddini önlemek için kullanılan siklosporin ilaçları bunlardan bazılarıdır. İlaca bağlı dişeti büyümelerinin mekanizması tam olarak anlaşılamamıştır; fakat multifaktöriyel etkenlere bağlı olduğu açıktır. Dişeti büyümelerinde önemli olan dental plak, predispozan etkenler, cinsiyet, yaş, tedavi süresidir. İlaca bağlı dişeti büyümelerinde, lokal etkenlerin ortadan kaldırılması, çok iyi bir oral hijyen ve periodontal tedavi ile kontrol edilebilir. Çalışmamızda nifedipin ve siklosporin A kullanımına bağlı gelişen gingival hiperplazi olgusunu, bu ilacın nadir görülen yan etkilerine dikkat çekmek amacıyla sunuyoruz.

Anahtar Kelimeler: Dişeti büyümeleri, gingival hiperplazi, kalsiyum-kanal blokerleri, immünsüpresanlar

\section{ABSTRACT}

Drug-induced gingival enlargement occurs as a side effect of some systemic drugs. Nifedipine drug used for the management of patients with hypertension and cyclosporine drug used to reduce organ transplant rejection are some of them. The mechanism of druginduced gingival enlargement is not entirely understood, but it is clear that due to the multifactorial influences. Important dental plaque growth in gums, predisposing factors, sex, age, duration of treatment. Drug- induced gingival enlargement, the elimination of local factors, a good oral hygiene and can be controlled by periodontal therapy. We report a case of gingival hyperplasia due to nifedipine and cyclosporine $\mathrm{A}$ use to draw attention to rare adverse effect of this drug.

Keywords: Gingival enlargement, gingival hyperplasia, calcium-channel blockers, immunosuppressants

\section{GİRIŞ̧}

Patolojik ve etyolojik faktörlere göre farklılık gösteren pek çok dişeti büyümesi vardır. Dişeti büyümesinde primer etken dental plaktır. Dental plağın sebep olduğu inflamasyon ilaçların kullanımına bağlı olarak ortaya çıkar. ${ }^{1}$ İlaca bağlı dişeti büyümesi Amerikan Periodontoloji Akademisi tarafından dental plağa bağlı dişeti hastalığı olarak sınıflandırıldı. Buna kanıt olarak, dişeti büyümesinin gelişmesi için dişetinde var olan enflamasyonun gerekli olması, ayrıca düzenli plak kontrolü ve etkin oral hijyende dişeti büyümesinin şiddetini veya potansiyelini azaltması ya da oluşumunu tamamen engellemesi gösterilmiştir. ${ }^{2}$
İlaca bağlı dişeti büyümeleri bazı sistemik ilaçların yan etkisi şeklinde oluşur. Epilepsi hastalığının kontrolü için kullanılan fenitoin, antikonvülsan olarak kullanılan (sodyum valproate, fenobarbiton, vigabatrin) ilaçlar, organ transplantasyonunda kullanılan immünsüpresif siklosporin ajanları, hipertansiyon hastalarında kullanılan kalsiyum-kanal blokerleri (nifedipin, verapamil, diltiazem, oksodipin, amlodipin) çoklukla dişeti büyümesi yapan farmakolojik ajanlardır. Diğer ilaçlar, antibiyotikler (eritromisin) ve hormonların yan etkisi ile ilişsili olabilir., ${ }^{3,4}$

Kalsiyum-kanal blokerleri grubunda yer alan nifedipine bağlı ilk dişeti büyümesi 1984 yılında

${ }^{*}$ Dicle Üniversitesi Diş hekimliği Fakültesi Periodontoloji Anabilim Dalı

** Dicle Üniversitesi Diş hekimliği Fakültesi Protetik Diş Tedavisi Anabilim Dalı 
çoğunlukla alt ve üst anterior bölgede 1-2 ay içerisinde ortaya çıktığı rapor edilmiştir. ${ }^{5}$ Dişeti büyümeleri genellikle interdental papilden başlar ve dişlerin labial yüzeylerine yayılır. Dişeti lobülleri lokal faktörlere bağı olarak enflamasyonu veya fibrotik görülebilir. Yapılan epidemiyolojik çalışmalarda, aşırı dişeti büyümesi sadece $\% 6$ civarında olduğu bildirilmiştir. ${ }^{6}$

Siklosporin-A (CSA) organ nakli hastalarında organ reddini önlemede ve romatoid artrit, sarkoidoz gibi immunolojik hastalıkların tedavisinde kullanilır. Günümüzde genellikle kortikosteroid ile birlikte yaygın olarak kullanılmaktadır. Büyümeler diğer ilaçlarda olduğu gibi interdental papilladan başlar. Daha çok anterior bölgede gözlenir. Kötü oral hijyen ile büyümelerin şiddeti artar. Genellikle marjinal gingiva ve interdental papiller ödematöz olup küçük mekanik travmalarda kanamaya yatkındır. CSA hiperplazisinde, dişsiz alveol mukozasında hiperplazi görülmemektedir. Bugüne kadar yapılan araştırmalarda CSA kullanılan hastalarda dişeti büyümesi görülme sıklı̆ı \%25-30 olduğu bildirilmiştir. ${ }^{7-9}$

İlaca bağlı dişeti büyümelerinin mekanizması kesin olarak anlaşılamamıştır; fakat dişeti büyümeleri multifaktöriyel etkenlere bağlanmıştır. Birçok çalışma göstermiş̧ir ki, dişeti büyümesine eğilimli olan bireylerde fenitoin, siklosporin ve kalsiyum-kanal blokerleriyle epitel dokusundaki keratositler, fibroblastlar ve kollajenlerle etkileşimleri dişeti büyümesine neden olabilir. ${ }^{10,11}$

$\mathrm{Bu}$ iki vakanın birincisinde hipertansiyon ilacı olarak nifedipin, ikincisinde böbrek transplantasyonu sonrasında organ reddini önlemek için siklosporin-A ilacı kullanan hastaların ilaca bağlı dişeti büyümelerinin klinik özellikleri, etyolojisi ve tedavisi ile ilgili bilgiler tartı̧̧ılmışıır.

\section{OLGU 1}

36 yaşındaki bayan hasta dişeti şikayeti ile kliniğimize başvurdu. Alınan anamnezinde hasta hipertansiyon için nifedipin $60 \mathrm{mg}$ (Adalat film tablet, Bayer, İstanbul) ilacı 2 yıldır kullandığını ifade etmiştir. Hastanın klinik muayenesinde ise üst ön vestibül bölgesinde yer alan, açık pembe renkte bazı dişlerin kole kısımlarda hafif koyu kırmızı renkte, ağrısız ve sondalamada dişetinde kanama gözlenmedi ( Resim 1a).

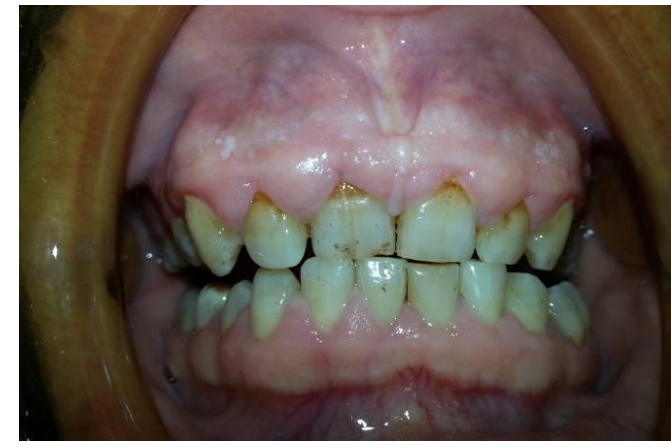

Resim 1a. Tedavi öncesi görünüm

Seymour ve ark.'nın ${ }^{12}$ hiperplazi indeksi değerlerine göre hastanın dişetleri skor 2 olarak belirlendi. Hastanın oral hijyeni iyi olmamasına rağmen supra ve subgingival diş taşları pek fazla gözlenmedi. Dişeti büyümesinin ilaç (nifedipin) kullanılmasından 1 yıl sonra geliştiği öğrenildi. Hastaya aydınlatılmış onam formu hakkında bilgi verilerek hastanın onayı alındı. Hastanın radyolojik muayenesinde üst ön bölgesinde ataşman ve kemik kaybı görülmedi; ama her iki santral dişin periodontal aralıkta bir genişleme olduğu tespit edildi. (Resim 1b).

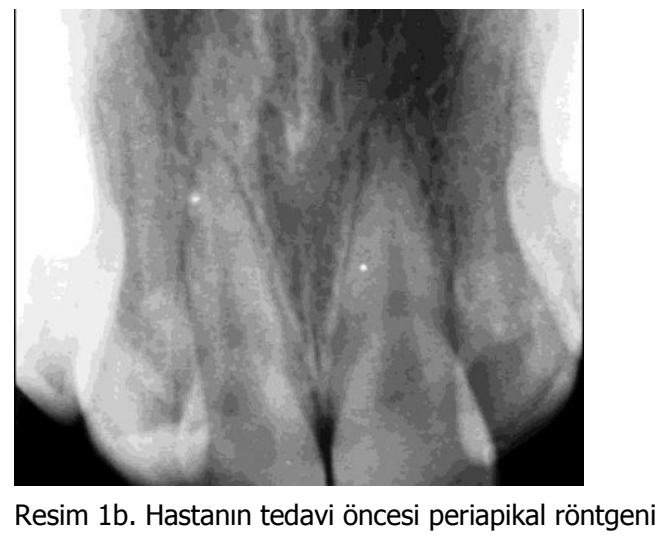

Faz I tedavi (supra ve subgingival diş taşları) uyguladıktan sonra oral hijyen eğitimi verildi. Ayrıca hastanın hekimi ile yapılan konsültasyon sonucu ilaç değişimi yapıldı. Hastaya hekimi tarafından irda $150 \mathrm{mg}$ (İrbesartan film tablet, Nobel, İstanbul) reçete edildi. Hastaya, 2 ay sonra gingivektomi ve gingivoplasti operasyonu yapıldı ve operasyon alanına periodontal pat (Peripac, Dentsply, İstanbul) yerleştirildi. 1 hafta sonra periodontal pat alınarak operasyon bölgesi serum fizyolojik \% 0.9 NaCI (Sodyum klorür çözelti, Eczacıbaşı, İstanbul) ile yıkandı (Resim 1c). 


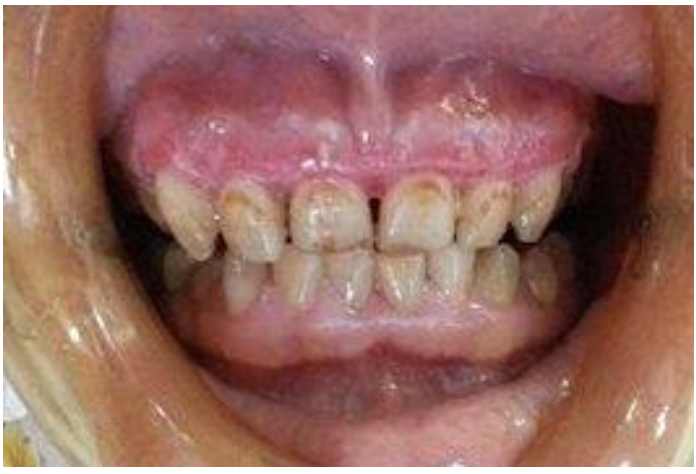

Resim 1c. Cerrahi tedavi sonrası görünüm

Hastaya oral hijyen eğitimi verilerek 1 ay sonra tekrar kontrole çağrıldı (Resim 1d).

Uygulanan tedaviden 1 yıldan fazlaca bir süre geçmesine rağmen, dişetinde herhangi bir nüks gözlenmedi. Hastaya ağız hijyeni hakkında detaylı bilgi verilerek takibine devam edildi

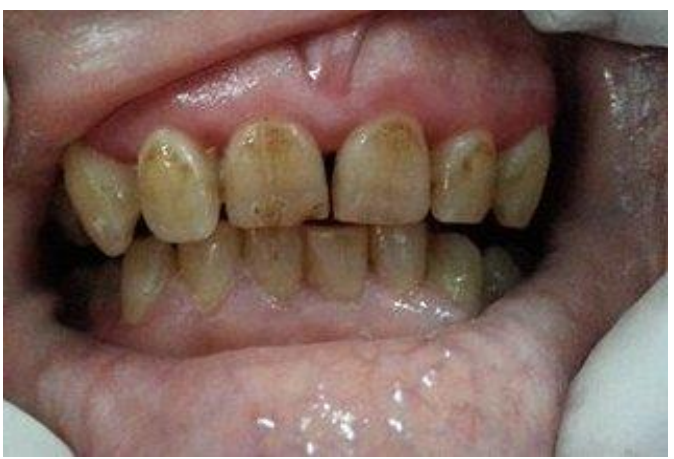

Resim 1d. Operasyondan 1 ay sonrası görünüm

\section{OLGU 2}

49 yaşındaki erkek hasta dişeti büyümeleri ile ilgili şikayeti üzerine kliniğimize başvurdu. Detaylı anamnezinde hasta 6 yıl önce böbrek nakli olduğunu ve bunun için siklosporin-A 100 mg (SandımmunNeoral jelatin kapsül, Novartis, İsviçre) ilacı kullandığı öğrenildi. Hastanın klinik muayenesinde ise alt ön labial ve lingual bölgede interdental papillada ve marjinal gingivada açık renkli ve palpasyonda belirli bir sertlikte fibröz görüntü veren lobuler ve papiller tarzda dişeti büyümesi (Resim 2a) ve sondalamada hafif kanama gözlemlendi.

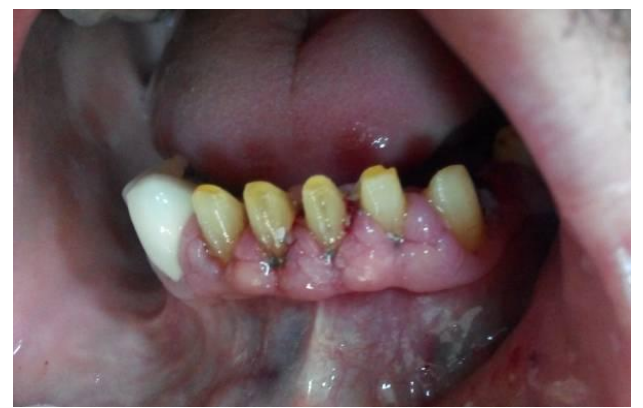

Resim 2a. Tedavi öncesi görünüm

Dişeti büyümesi hiperplazi indeksine göre skor 3 olarak belirlendi. Hastanın oral hijyeni iyi değildi ve yaygın supra ve subgingival diş taşı mevcuttu. Hastamıza onam formu ile ilgili bilgi verilerek hastanın onayı alındı. Ağız hijyen eğitimine takiben geleneksel periodontal tedavi uygulandı ve hastanın alt çene protezleri söküldü. Hastanın radyolojik muayenesinde alt ön bölgesinde ataşman ve kemik kaybı gözlemlendi (Resim 2b).

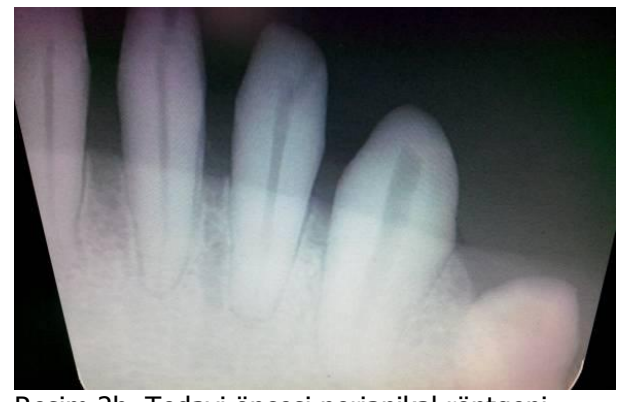

Resim 2b. Tedavi öncesi periapikal röntgeni

Hastanın hekimi ile yapılan konsültasyon sonucu hastanın ilacı değiştirilmedi ve 3 hafta sonra amoksisillin 1000 mg (Largopen film tablet, Bilim, İstanbul) proflaksi yapılarak dişeti büyümeleri cerrahi yöntemle (gingivektomi ve gingivoplasti) uzaklaştırıldı ve operasyon alanına periodontal pat (Peripac, Dentsply, İstanbul) konuldu. 1 hafta sonra periodontal pat alınarak serum fizyolojik \%0.9 NaCI (Sodyum klorür çözelti, Eczacıbaşı, İstanbul) ile yıkandı. Hasta 10 gün sonrasına kontrole çağrıldı (Resim 2c).

Hastanın operasyondan 1 ay sonrası ve geçici protezleri simante edilmiş haliyle kontrole çağrıldı (Resim 2d).

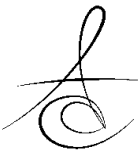




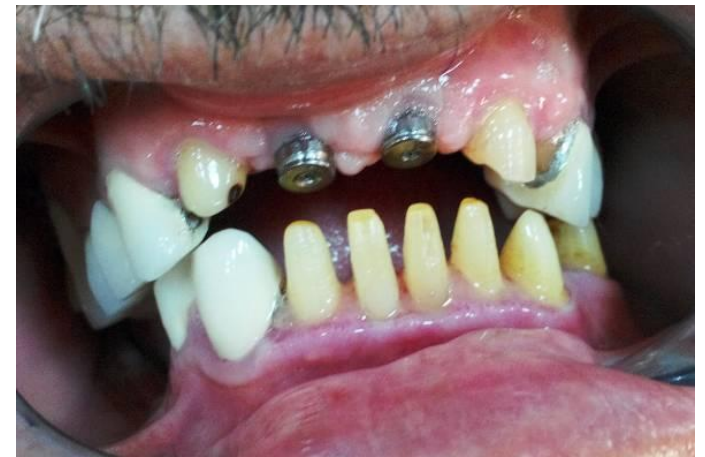

Resim 2c. Tedaviden 10 gün sonrası görümü

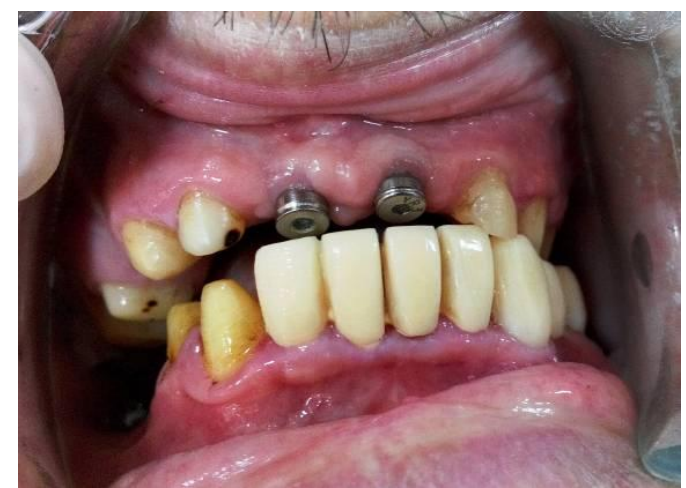

Resim 4. Tedaviden 1 ay sonrası ve geçici protezlerin simante edilmiş görünümü

\section{TARTIŞMA}

Antihipertansif ilaçlar, kalsiyum kanal-blokerleri grubunda yer alırlar. Birçok anjina formları, periferal vasküler hastalığı olan yaşlılarda ve bazı akut myokart enfarktüslerde kullanılmaktadır. Antihipertansif ilaçların en yaygın yan etkileri; baş ağrısı, baş dönmesi, yüzde kızarma ve ödemdir. Daha sonra bu ilaçların dişeti büyümesine neden olduğu rapor edildi. ${ }^{5}$

Klinik görünüm olarak nifedipine bağlı dişeti büyümeleri ilgili ilaçların kullanımını takiben çoğunlukla 1-2 ay sonra interdental bölgeden başlar, hem anterior hem de posterior bölgede görülmesine rağmen daha çok alt ve üst ön vestibül bölge ve inflamasyonun yoğun olduğu alanlarda gözlemlenmiştir. Ayrıca dişsiz bölgelerde dişeti büyümesine rastlanmamıştır. Bu ilacın önemli yan etkisi olan dişeti büyümesini hangi mekanizmayla oluşturduğu tam olarak bilinmemektedir. ${ }^{13,14}$

İlaca bağlı dişeti büyümelerinde en etkili tedavi şekli ilacın değiştirilmesi ya da kesilmesidir. Bu protokol uygulandıktan 1-8 hafta içinde dişeti lezyonları düzelebilir; fakat uzun süre dişeti lezyonlarına sahip hastalar bu tedaviye cevap vermemektedirler. ${ }^{15}$ Bizim bu hastamızda ilk etapta hastanın hekimi ile yapılan konsültasyon sonrası alternatif bir ilaçla değiştirildi; ancak 2 ay boyunca farklı bir ilaç kullanmamıza rağmen dişeti büyümeleri düzelmediğinden dişeti lezyonları cerrahi olarak uzaklaştırıldı.

CsA, organ transplantasyonu olan hastalarda organ reddini önlemek için kullanılır. Başlangıçta böbrek nakli olan hastalarda, daha sonra karaciğer, pankreas, kemik iliği, kalp ve akciğer nakillerinde kullanıldı. Ayrıca romotoid artrit gibi birçok oto-immün hastalıkta da kullanılmıştır. Bu ilaç yaygın olarak nefrotoksisite, hipertansiyon, hepatoksisite ve nörotoksisite gibi yan etkilere sahiptir. Oral yan etkileri ise, dişeti büyümesi ve nadir olarak lingual fungiform papilla hipertofisine neden olur. CsA dişetlerinde absorbsiyonu yavaş bir şekilde olur ve bireyler arasında serum konsantrasyonu farklıdır. Dişeti büyümesi interdental papilladan başlar, sıklıkla dişlerin anterior ve labial bölgesinde görülür. Büyümeler genellikle yapışık dişeti ile sınırıdır; ama dişlerin koronal ve oklüzal kısımlarına kadar ulaşınca, hastalarda konuşma ve çiğneme problemleri ortaya çıkar. CSA tarafından etkilenen dişeti büyümeleri, fenitoinden etkilenen dişetlerine göre daha hiperemik ve dişeti sondalamasında kanamaya daha eğilimli olduğu bildirilmiştir. ${ }^{16,17}$ Bizim vakamızda da sondalamada dişetinde kanama olması bu kaynakça ile uyumludur.

CsA dişeti hiperplazisinde, dişlerin bulunmadığı alveol mukozasında hiperplazi görülmemektedir. İlaca bağlı dişeti büyümelerinin klinik görünümleri benzer olduğu için birbirinden ayırt edilmesi kolay değildir. ${ }^{18}$ Fakat CsA bağlı dişeti büyümesinde lobuler tarzda dişeti büyümelerinin üzerinde papiller tarzda büyümeler görülür. Büyümelerde önemli olan dental plak, predispozan etkenler, cinsiyet, yaş, tedavi süresidir. ${ }^{19}$ Bizim vakamızda hastanın alt ön kesicilerinde metal destekli porselen köprü kullanılması, dişetlerinin büyümesine ilave bir travma oluşturabilir. Çünkü köprü protezlerin dişetiyle uyumlu olmaması ve bu protezlerin plak birikimi için ideal alanlar olması dişeti büyümelerin şiddetini artırabilir.

Dişeti büyümesini etkileyen faktörlerden birisi de cinsiyettir. Erkeklerde bayanlardan 3 kat fazla dişeti büyümesi görülür. Yaş azaldıkça büyümenin etkisi artar. CsA ve nifedipinin günlük dozu ile arasında bir bağlantı kurulmuşsa da, çoğu araştırmada ilacın dozu ile ilgili önemli bir ilişki bildirilmemiştir. ${ }^{20}$ 
İlaca bağı dişeti büyümeleri, lokal etkenlerin ortadan kaldırılması, çok iyi bir oral hijyen ve periodontal tedavi ile kontrol edilebilir. Bu hastalar 3 aylık düzenli aralıklarda kontrole çağırılarak periodontal tedavilerinin yapılması önemlidir. Hastaların hekimleri ile iletişime geçilip ilaçların değiştirilmesi gerekebilir. İlaç değiştirildikten 1-8 hafta sonra dişeti lezyonları düzelebilir. Nifedipin kullanılan hastalarda diltiazem ya da verapamil ile değiştirildiğinde dişeti büyümesi azalabilir. Böbrek transplantasyon hastalarında alternatif bir ilaç olarak kullanılan takrolimusun dişeti büyümesine neden olmadığı bildirilmiştir. Fakat kalp transplantasyonu olan hastalarda durumu stabilse ve CsA'nın yan etkileri kontrol altına alınabiliyorsa, ilaç değiştirilmesine gerek olmayabilir. ${ }^{19,21}$

Büyümeler genellikle ön bölge labialde görüldüğünden, cerrahi tedavi fonksiyondan ziyade estetik problemlerden dolayı uygulanır. Genellikle cerrahi olarak gingivektomi ve gingivoplasti uygulanır. Lazer kullanımı, postoperatif hemostaz sağlayan ve iyileştirmeyi hızlandıran diğer bir cerrahi tedavi seçeneğidir. Özellikle immünsupresif ilaç kullanılan hastalarda, hastanın hekimine konsültasyon yapılmalıdır. Hekimin tavsiyesi doğrultusunda tedaviden 1 saat önce antibiyotik proflaksisi yapılarak tedaviye başlanılmalıdır. CSA kullanılan hastalarda primer ve sekonder kan basınc cerrahi girişim için bir kontraendikasyondur. Hastanın hipertansiyonu kontrol altında değilse, operasyon sonraSI oluşan hemoroji riski nedeniyle ertelenmelidir. ${ }^{19,22,23}$

İlaca bağı dişeti büyümelerin klinik ve histolojik görümü benzerdir. Bu büyümeler genellikle interdental papilladan başlar ve genellikle yapışık dişeti ile sınırıdır. Diğer dişeti büyümeleri (herediter, iatrojenik, vb.) dişetinin bütün elemanları ile büyümesi şeklindedir. Yani büyümeler hücre düzeyinde olur. Dişeti büyümelerinde çok sık aralıklarla periodontal tedavi yapılmalı ve oral hijyen eğitimi verilmelidir. Hastanın hekimi ve periodontologun birlikte çalışmasıyla başarıı bir tedavi gerçekleşmiş olur.

\section{KAYNAKLAR}

1. Brunet L, Miranda J, Farre M, Berini L, Mendieta C. Gingival enlargement induced by drugs. Drug Saf. 1996;15:219-31.

2. Foisie, Lieutenant Commander Craig $\mathrm{K}$, and Captain Thu P. Getka. Drug-induced gingival enlargement. Clin Update, 2008;6:1-2.
3. Camargo PM, Melnick PR, Pirih FQM, Lagos R, Takei $\mathrm{HH}$. Treatment of drug-induced gingival enlargement: aesthetic and functional considerations. Periodontology 2000, 2001; 27:131-8.

4. Seymour RA, Ellis JS, Thomason JM. Risk factors for drug-induced gingival overgrowth. J Clin Periodontol, 2000; 27:217-23.

5. Sunil PM, Nalluswami JS, Sanghar SJ, Joseph I. Nifedipine-induced gingival enlargement: Correlation with dose and oral hygiene. J Pharm Bioal Sci 2012;4: 191-3.

6. Dongari-Bagtzoglou A, Research Science and Therapy Committee, American Academy of Periodontology. Drug-associated gingival enlargement. Informational paper. J Periodontol, 2004; 75: 1424-31.

7. Thomas DW, Newcombe RG, Osborne GR. Risk factors in the development of cyclosporine-induced gingival overgrowth. Transplantation, 2000; 69: 522-6.

8. Boltchi FE, Rees TD, Iacopino AM. Cyclosporine ainduced gingival overgrowth: a comprehensive review. Quintessence Int, 1999; 30: 775-83.

9. Butler RT, Kalkwarf KL, Kadhal WB. Drug-induced gingival hyperplasia: phenytoin, cyclosporine and nifedipine. JADA, 1987; 114: 55-60.

10. Vescovi $P$, Meleti $M$, Manfredi $M$, Bonanini $M$. Pathogenesis of cyclosporin induced gingival overgrowth. Min Stomatol 2003;52:219-9.

11. American Academy of Periodontology. Informational paper: drug-associated gingival enlargement. J Periodontol, 2004;75:1424-31.

12. Seymour RA, Smith DG, Tumbull DN: The effects of phenytoin and sodium valporate on the periodontal health of adult epilectic patients. J Clin Periodontal, 1985;12:413-9.

13. Ciantar $M$. Nifedipine-induced gingival overgrowth: remission following non-surgical therapy. Dent Update. 1996;23:374-7.

14. Bokor-Bratic M, Vuccovic N, Selakovic S. Gingival hyperplasia during treatment with nifedipine: Med Pregl. 1998;51: 445-8.

15. Bharti V, Bansal C. Drug-induced gingival overgrowth: The nemesis of gingiva unravelled. J Indian Soc Periodontol, 2013;17:182-7. 
16. Kandwal, Abhishek. Drug Induced Gingival Enlargement. J Dent Sciences, 2012;3: 51-2.

17. Kazancıoğlu, H. O, Erişen, M, Demirtaş, N, Türkmen, A, \& Ak, G. Dişeti büyümesi meydana getiren ilaçlar ve tedavileri. J Istanbul Uni Fac Dent, 2013 ; 47: 66-72.

18. Khocht A, L.C. Periodontal management of gingival overgrowth in the heart transplant patient: A case report. J Periodontol, 1997;68:1140-6.

19. Kara C, Yağız H, Zihni M. Nifedipin tedavisine bağı ortaya çıkan diş eti büyümesi( olgu sunumu). Atatürk Üniv Diş Hek Derg 2006;16:59-62.

20. Radwan-Oczko M, Boratynska M, Klinger M, Zietek M. Risk factors of gingival overgrowth in kidney transplant recipients treated with cyclosporine $A$. Ann Transplant, 2003, 8: 57-62.

21. Hernandez G, Arriba L, Lucas M, Andres A. Reduction of severe gingival overgrowth in a kidney transplant patient by replacing cyclosporin a with tacrolimus. J Periodontol, 2000; 71: 1630-6.

22. Pick RM, Colvard MD. Current status of lasers in soft tissue dental surgery. Review. J Periodontol, 1993; 64: 589-602.

23. James JA, Jamal S, Hull PS, Macfarlane TV, Campbell BA, Johnson RWG, Short CG: Tacrolimus is not associated with gingival overgrowth in renal transplant patients. J Clin Periodontol, 2001; 28: 848-52.

\section{Yazışma Adresi}

Dt. Abdulsamet TANİK

Dicle Üni. Diş Hekimliği Fakültesi

Periodontoloji Anabilim Dalı.

Diyarbakır/ Sur

e-mail: samet.120a@gmail.com 